\title{
The Impact of Remittances and Foreign Aid on Savings/Investment in Sub-Saharan Africa (SSA)
}

\author{
Yéro Baldé ${ }^{1}$ \\ Laboratoire d'Analyse et de \\ Prospective Economique (LAPE) \\ Université de Limoges, FRANCE
}

JANUARY 2010

\begin{abstract}
This study investigates the macroeconomic impact of remittances on savings and investment in Sub-Saharan Africa (SSA). It also analyzes comparatively the effectiveness of remittances and foreign aid (official development assistance) in promoting savings and investment. We use a respective sample of 37 and 34 SSA countries over the period 1980-2004. Using OLS and instrumental variables (2SLS) estimation methods with country fixed-effects, the results suggest that both remittances and foreign aid promote savings and investment in Sub-Saharan Africa, but remittances are strongly more effective. The coefficients of remittances are 6 to 7 times higher than those of foreign aid. A 10\% increase in remittances increases savings by $7 \%$ and investment by $6.5 \%$, while the same $10 \%$ increase in foreign aid increases savings and investment by respectively $1.6 \%$ and $1 \%$. According to these results, remittances, although less important in volume and in percentage of GDP, are more effective in boosting savings and investment in SSA than foreign aid. However, when foreign aid is efficiently used, it can be an important complement to remittances by allowing vulnerable households to have income above the threshold subsistence's level so they can use larger share of remittances for savings and investment purposes.
\end{abstract}

Keywords: Migration, Remittances, Foreign Aid, Savings, Investment, Development, Sub-Saharan Africa (SSA)

JEL Classification : F22, F24, F35, O11, E21, E22

\footnotetext{
${ }^{1} \mathrm{PhD}$ Student in Economics at the University of Limoges, 5 rue Félix Eboué, 87031, Limoges, France. Email : yero.balde@,etu.unilim.fr; Phone : (0033) 625-457-144
} 


\section{Introduction}

The literature on the relationship between foreign aid (also known as official development assistance), savings and investment in developing countries has been very abundant during the last thirty years, studies examining both micro and macro level as well as regional or national level. However, the results are mixed and vary widely depending on the sample and the econometric method used by authors. Weisskopf (1972), Fry (1978), Gupta and Islam (1983) show that the impact of aid on savings in developing countries is significantly negative. Hadjimichael et al. (1995) find that when one considers Sub-Saharan Africa (SSA), the impact of foreign aid is negative for savings but mixed for investment. However, by dividing the sample into two subgroups, one with negative growth rates and another one with positive growth rates, foreign aid fosters savings and investment for the subgroup with positive growth and therefore in the presence of favourable economic conditions. The negative effect however persists for the subgroup with negative growth. On the other hand, Mosley (1987) did not find a significant relationship.

While the literature has extensively discussed the effectiveness of foreign aid in SSA; the impact of migrants' remittances in this region received less attention particularly at the macroeconomic level. This could be explained by the relative low share of remittances received by this region (only $6 \%$ of remittances to developing countries in 2008, Table 1). This however is about 21 billion dollars with an increase of almost 254\% between 2003 and 2008, representing the largest increase of the amount over this period.

Graph 1 below shows that remittances represent an important share of GDP for some SSA countries such as Lesotho $(24 \%)$ or Cape Verde $(8 \%)$. Another factor that could explain the low interest on the study of remittances in SSA in the literature would be the relatively lower share of remittances compared to foreign aid. 
Table 1: Place of SSA in Remittances received by region, billion US \$ and \%, 2003-2008

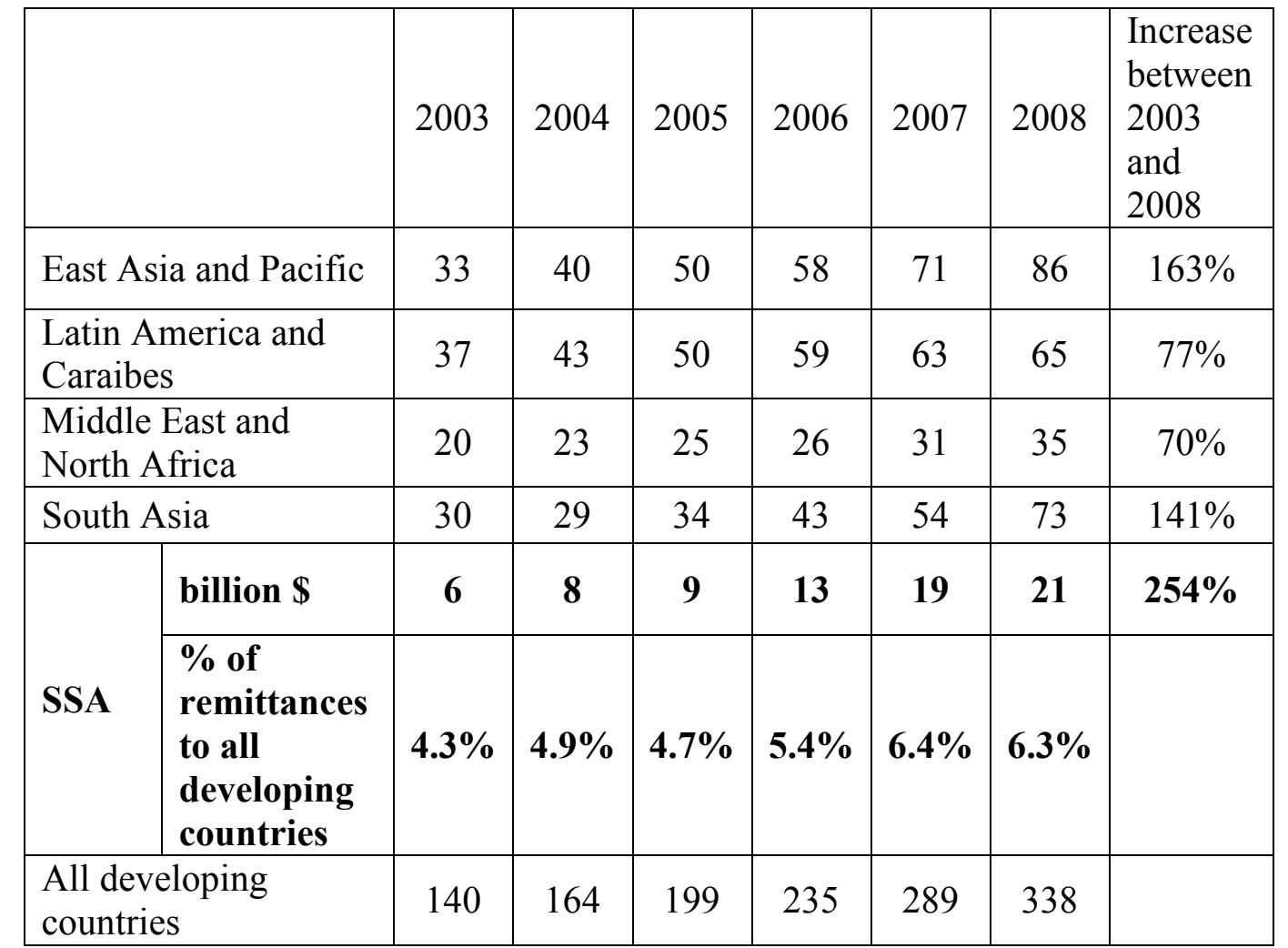

Source: Data from World Bank staff estimates (2009) based on the IMF's BOP statistics Yearbook (2008) 


\section{Graph 1: Remittances in \% of GDP in SSA, 2006}

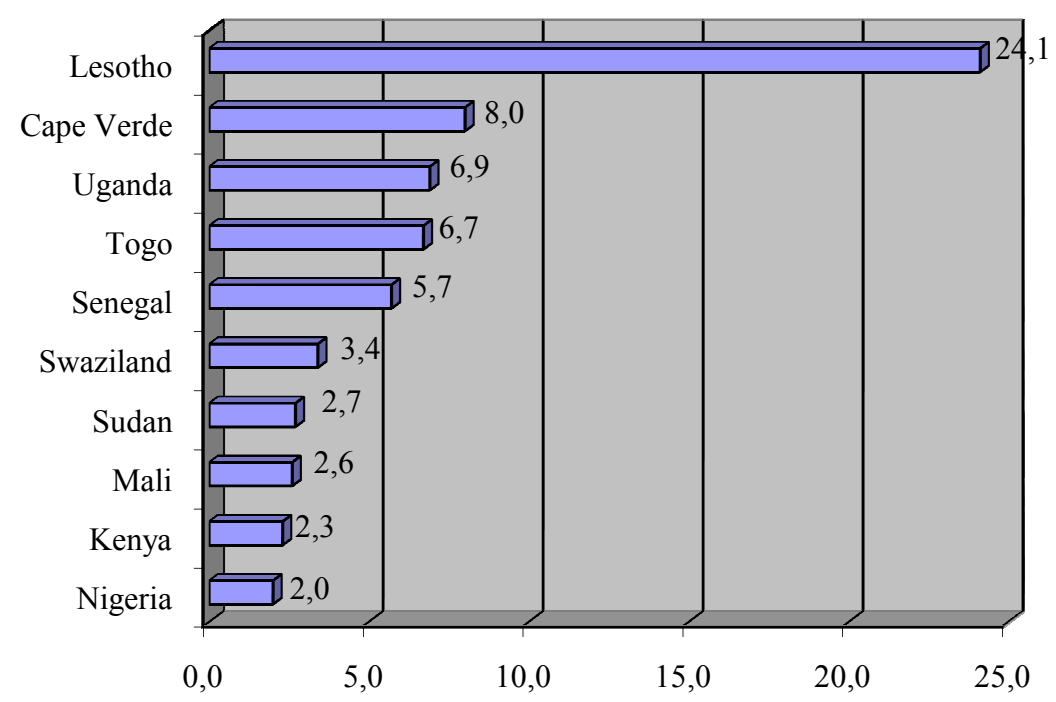

Source: Our calculation based on World Development Report (2008) for GDP and World bank staff estimates (2009) for remittances

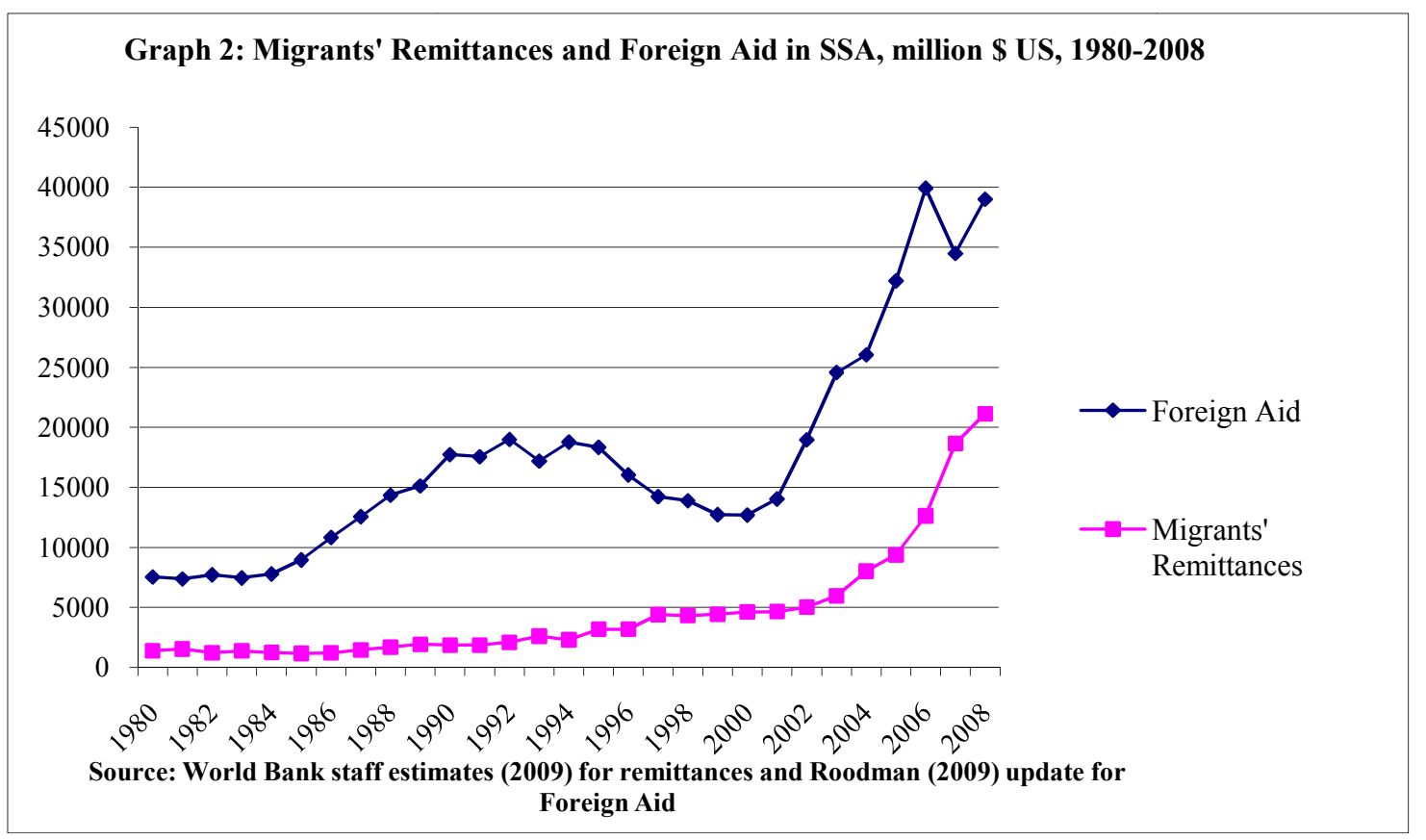


Graph 2 above shows the dependence of SSA on foreign aid as a source of external capital and the low share of migrants' remittances compared to foreign aid. Foreign aid accounts for up to more than 15 times the remittances in SSA depending on the year considered. This is in contrary with other developing regions where remittances are more important than foreign aid since the mid-90s. Despite these large flows, Baldé (2009) finds in a previous paper that remittances and foreign aid did not stimulate growth in SSA.

In this paper, we investigate two important points: first, we analyze whether remittances stimulate savings and investment in SSA. Second, we compare the effectiveness of remittances and foreign aid in promoting savings and investment in this region. While the link between aid, savings and investment in SSA has been widely documented, our study is the first one that investigates the macroeconomic impact of remittances on savings and investment in this region and compares the effectiveness of remittances and foreign aid on stimulating these two variables in a sample of 37 and 34 Sub-Saharan African countries over a long period (1980-2004).

\section{1- Remittances, Savings and Investment : A Review of Literature}

On the current debate on migration and development, many researchers have pointed out that the way in which migrants and households spend remittances have a significant effect on the development of local economies. In the 70 s until the late $80 \mathrm{~s}$, the economic literature has not found a positive relationship between remittances and development, arguing that remittances are mainly used for subsistence consumption (food, clothing...), non-productive investments, repayment of debts, and that these kinds of expenditures tend to have little positive impact on local economies development. Rempel and Lobdell (1978) note that remittances are mainly devoted to daily consumption needs. Lipton (1980) estimates that purchases of consumer goods related to daily needs absorb about $90 \%$ of remittances received. 68 to $86 \%$ of the Mexican migrants' remittances are used for consumption (Massey et al. (1987)). 
However, more recent studies conducted in most cases for Latin America and Asia found that migrants and households spend a share of remittances on investment goods (i.e. education, housing and small business), and that these types of expenses would strengthen the human and physical capital of the recipient countries. According to Mishra (2005), an increase of $1 \%$ in remittances in 13 Caribbean countries leads to an increase in domestic private investment by $0.6 \%$ (relative to GDP). Funkhouser (1992) for El Salvador, Yang (2004) for the Philippines, Woodruff and Zenteno (2002) for Mexico highlight that remittances would have reduced credit constraints in the receiving households and encouraged entrepreneurship in these countries. Adams et al. (2008) found that households in Ghana treat remittances as any other source of income and there is no disproportionate tendency to spend it on consumption. Mesnard (2001) finds that migration, through enrichment of some Tunisian workers abroad, allows investment in more productive activities in their home country. Tests conducted by Leon-Ledesma and Piracha (2001) for 11 countries of Central and Eastern Europe and Drinkwater et al. (2003) on 20 developing countries show that remittances contribute significantly in increasing the level of investment in their home countries.

\section{2- Data and Variables Description}

Our data come from two main sources: The World Development Indicators 2006 of the World Bank and David Roodman's Index of Donor Performance data compilation on Foreign Aid originally published in 2005 and updated in 2009 within the Center for Global Development. Table 5 in the appendix shows the definition of the variables.

Due to the lack of continuous observations, some countries are excluded from the final estimation. Only 37 and 34 out of 48 SSA countries are considered respectively in the saving and investment estimation.

Remittances are defined by IMF as the sum of workers remittances, compensation of employees and migrants' transfer. However as already pointed out by 
OECD and many other studies, there is confusion in remittances recording, which can seriously affect the comparability and reliability of data. Remittances are often misclassified as export revenue, tourism receipts and deposits of non resident. According to Gubert (OECD 2006), even data from the recording method of the IMF are very limited and confused and seriously call into question the estimations. First, the calculation of remittances flows by the IMF method overestimates the actual flows as a share of compensation of employees is the gross wage of which a part is necessarily spent in the host country and is never remitted, and secondly that compensation includes the salary of individuals who are not even migrants such as local staff of embassies (who works in his own country), consulates and international organizations based abroad but operating locally.

Moreover, these flows may also be largely underestimated because they do not include remittances through informal channels (cash sent through friends or family members, remittances in kind: jewellery, clothing, electronics and other consumer goods ...). Some studies (World Bank (2006)) consider these informal flows to over $50 \%$ of total official remittances recorded. When recording in-kind remittances, the country torn between recording as remittances or as goods import.

But despite these shortcomings, data from World Development Indicators and the "Balance of Payment Statistics Yearbook" of IMF are the best and by far the most comprehensive source of information on remittances to the macro level.

\section{3- Methodology}

We use unbalanced panel because of insufficient data on certain periods. The objective is to estimate the impact of remittances and foreign aid on savings/investment in Sub-Saharan Africa from 1980 to 2004

Our empirical study consists of two econometric relationships: 1) the relationship between migrants' remittances, foreign aid and savings, and 2) the relationship between migrants' remittances, foreign aid and domestic investment in SSA. We use two 
samples of 37 and 34 SSA countries that have sufficient annual data over the period 1980-2004 so that a panel data method can be used. We rely on the economic literature that has found a number of variables as determinants of savings and investment.

F-test allows us to reject the null hypothesis of individual homogeneity at $1 \%$ level and conclude to the presence of individual specificities. The good model to use here is either fixed-effect or random-effect. We check if these specificities are fixe or random by performing the Hausman test. The results allow us to choose the fixed effects model at $1 \%$ level. The introduction of country specific effects in the model will allow taking into account a possible heterogeneity of data and unobservable characteristics of countries. We therefore estimate our relations with the Ordinary Least Squares (OLS) method taking into account the presence of country fixed effects. Using White's method correction solves the problem of heteroscedasticity.

However, the former literature underline the possibility that GDP per capita is endogenous to both saving and investment. This means that an increase in GDP per capita may lead to increase of both saving and investment; but also an increase in saving and investment may lead to increase of GDP per capita. In this situation, our estimated coefficients with OLS method may be biased. The existence of such causality would result in a correlation between the control variables and error term, which violates the assumptions of a linear regression model. It is in this case difficult to assess the effect of an individual variable and to isolate its influence on saving and investment. Estimation of such a model would lead to an endogeneity bias. To address this problem, we use the Two-Stage Least Squares (TSLS) instrumental variables method and try to find variables highly correlated with the endogenous variable, but independent to the error term. The problem with this method is to find good instruments. In this study, we controls for endogeneity by using "internal instruments", that is, instruments based on lagged values of the explanatory variables that are endogeneous. In the econometric theory, a good instrument (exogenous) variable may be endogenous variable itself lagged 2 periods. We then re-estimate our equations with the instrumental variables 
method (2SLS) and use GDP per capita lagged two periods as an instrument of GDP per capita.

Moreover, as remittances and saving may be also correlated, we use the residual series collected from the estimation of saving-remittances equation as a proxy of saving variable, this solve the potential correlation problem between remittances and saving and between income per capita and saving.

We control for unobservable country specificities by including a country specific fixedeffects $\alpha_{i}$.

\section{3- 1. Remittances, Aid and Savings in Sub-Saharan Africa}

Looking into the relationship between remittances, foreign aid and savings, we estimate the following equation:

$$
G S_{i t}=\beta_{0}+\beta_{1} G D P P C_{i t}+\beta_{2} R_{E M I T}+\beta_{3} A I D_{i t}+\beta_{4} D E P_{-} I N T_{i t}+\beta_{5} I N F L A T_{i t}+\alpha_{i}+\varepsilon_{i t}
$$

where $G S_{i t}$ is savings of country $i$ at the date $t$. Economic variables identified in the literature as determinants of savings are $G_{D P P C}$ (Servén and Solimano, 1993, Wai and Wong, 1982), deposit interest rate $D E P_{-} I N T_{i t}$ (Greene and Villanueva, 1991),

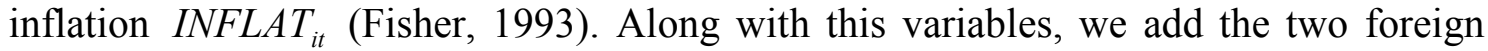
capital flows: migrants' remittances $R E M I T_{i t}$ and foreign aid $A I D_{i t}, \alpha_{i}$ is a country specific fixed-effects and $\varepsilon_{i t}$ is the error term.

\section{3- 2. Remittances, Aid and Investment in Sub-Saharan Africa}

In investigating the relationship between remittances, foreign aid and investment, we estimate the following equation:

$$
\begin{aligned}
I N V_{i t}= & \beta_{0}+\beta_{1} G D P P C_{i t}+\beta_{2} R_{E M I T}+\beta_{3} A I D_{i t}+\beta_{4} L E N D_{-} I N T_{i t}+\beta_{5} G S_{i t}+\beta_{6} O P E N_{i t} \\
& +\alpha_{i}+\varepsilon_{i t}
\end{aligned}
$$


where $I N V_{i t}$ is investment of country $i$ at the date $t$. According to the economic literature, income per capita $G D P P C_{i t}$ (Wai and Wong, 1982, Greene and Villanueva, 1991), lending interest rate $L E N D_{-} I N T_{i t}$ (Greene and Villanueva, 1991), openness OPEN $_{i t}$ (Levine and Renelt, 1992), and savings $G S_{i t}$ (Feldstein and Horioka, 1980) are determinants of investment. Remittances $R E M I T_{i t}$ and foreign aid $A I D_{i t}$ are added as our variables of interest. $\alpha_{i}$ is the country fixed-effects and $\varepsilon_{i t}$ the error term.

\section{4- Estimation Results}

The OLS and 2SLS results are very similar. GDP per capita, as expected, positively and significantly influences savings and investment. The capacity of countries to mobilize savings to finance investment depends on its level of development. High deposit interest rates encourage savings, the coefficient is positive and significant at 5\% level; however, high lending interest rates inhibit investment. Inflation is detrimental to savings while economic openness encourages investment. Savings is also a determinant of investment; its coefficient is positive and significant at $1 \%$ level regardless to the estimation method used. 
Table 2: Remittances, Foreign Aid and Savings in SSA

\begin{tabular}{|c|c|c|}
\hline \multirow[b]{2}{*}{$\begin{array}{l}\text { Dependant Variable : } \\
\text { Savings (\% of GDP) }\end{array}$} & \multicolumn{2}{|c|}{ Econometric Method } \\
\hline & $\begin{array}{c}\text { (1) } \\
\text { OLS-Fixed } \\
\text { Effects } \\
\end{array}$ & $\begin{array}{c}\text { (2) } \\
\text { 2SLS-Fixed } \\
\text { Effects } \\
\end{array}$ \\
\hline GDP per capita & $\begin{array}{c}0.004 * * \\
(2.643)\end{array}$ & $\begin{array}{l}0.0007 \\
(0.362)\end{array}$ \\
\hline Remittances & $\begin{array}{c}0.757 * * * \\
(3.129)\end{array}$ & $\begin{array}{c}0.697 * * * \\
(2.788)\end{array}$ \\
\hline Foreign Aid & $\begin{array}{c}0.163 * * \\
(2.430)\end{array}$ & $\begin{array}{c}0.159 * * \\
(2.437)\end{array}$ \\
\hline Deposit interest rate & $\begin{array}{c}0.145 * * \\
(2.525)\end{array}$ & $\begin{array}{c}0.130 * * \\
(2.200)\end{array}$ \\
\hline Inflation & $\begin{array}{c}-0.046^{* *} \\
(-2.308)\end{array}$ & $\begin{array}{l}-0.044^{*} \\
(-1.831)\end{array}$ \\
\hline Constant & $\begin{array}{c}4.687 * * * \\
(2.814)\end{array}$ & $\begin{array}{c}8.050 * * * \\
(4.131)\end{array}$ \\
\hline Observations & 513 & 495 \\
\hline Number of id & 37 & 37 \\
\hline R-squared & 0.69 & 0.70 \\
\hline Adjusted R-squared & 0.66 & 0.67 \\
\hline F-statistic & $25.77 * * *$ & $25.35 * * *$ \\
\hline
\end{tabular}

Migrants' remittances and foreign aid both have positive coefficients, but their significance and size vary for these two variables. In the savings equation, the coefficient of foreign aid is significant at $5 \%$ level in the two specifications, OLS and two-stage least squares, whereas in the investment equation, we find foreign aid to be respectively significant at $1 \%$ and $5 \%$ level in determining investment. On the other hand, we find remittances coefficient highly significant at $1 \%$ level no matter the specification. More importantly, the estimated coefficients of remittances are higher than those of foreign aid, suggesting that remittances may stimulate more savings and investment in SSA than foreign aid. 
Table 3 : Remittances, Foreign Aid and Investment in SSA

\begin{tabular}{|c|c|c|}
\hline \multirow{2}{*}{$\begin{array}{l}\text { Dependant } \\
\text { variable : } \\
\text { Investment (\% of } \\
\text { GDP) } \\
\end{array}$} & \multicolumn{2}{|c|}{ Econometric Method } \\
\hline & $\begin{array}{c}(1) \\
\text { OLS-Fixed Effects }\end{array}$ & $\begin{array}{c}(2) \\
\text { 2SLS-Fixed Effects }\end{array}$ \\
\hline GDP per capita & $\begin{array}{l}0.0028 * * \\
(2.382)\end{array}$ & $\begin{array}{l}0.004 * * * \\
(2.813)\end{array}$ \\
\hline Remittances & $\begin{array}{c}0.646^{* * *} \\
(3.220)\end{array}$ & $\begin{array}{c}0.657 * * * \\
(3.308)\end{array}$ \\
\hline Foreign Aid & $\begin{array}{c}0.098 * * * \\
(2.644)\end{array}$ & $\begin{array}{l}0.093 * * \\
(2.558)\end{array}$ \\
\hline Lending interest rate & $\begin{array}{c}-0.132 * * \\
(-2.518)\end{array}$ & $\begin{array}{l}-0.081 * \\
(-1.937)\end{array}$ \\
\hline Openness & $\begin{array}{c}0.048 * * * \\
(3.068)\end{array}$ & $\begin{array}{l}0.042 * * * \\
(2.915)\end{array}$ \\
\hline Savings & $\begin{array}{l}0.255^{* * *} \\
(5.328)\end{array}$ & $\begin{array}{l}0.279 * * * \\
(6.105)\end{array}$ \\
\hline Constant & $\begin{array}{c}11.69 * * * \\
(5.347)\end{array}$ & $\begin{array}{c}9.769 * * * \\
(4.561)\end{array}$ \\
\hline Observations & 411 & 395 \\
\hline Number of id & 34 & 34 \\
\hline R-squared & 0.74 & 0.76 \\
\hline Adjusted R-squared & 0.72 & 0.74 \\
\hline F-statistic & $27.75 * * *$ & $29.52 * * *$ \\
\hline
\end{tabular}

According to our results, an increase of $10 \%$ in remittances in SSA increases savings by $7.6 \%$ in the OLS estimates (Table 2 , column 1) and by $7 \%$ when we control for endogeneity (Table 2, column 2), while the same increase of $10 \%$ in foreign aid increases savings by only $1.6 \%$ (Table 2, column 1 and 2 ). We find the same observations in the second regression (Table 3 ) where an increase of $10 \%$ in remittances increases investment by $6.5 \%$ regardless of the econometric methodology used. The same increase of $10 \%$ in foreign aid increases investment in SSA by only $1 \%$. Baldé (2009) find that foreign aid did not promote economic growth in SSA. Yet, as we have 
noted, foreign aid has always been more important in terms of volume and in \% of GDP in SSA (Graph 2), with nearly \$39 billion in 2008 against 21 billion in remittances. From 1980 to 2004, aid has on average accounted for almost 12\% of GDP in SSA countries against $3 \%$ for remittances (Table 4 and 5 ).

\section{5- Comparative Analysis of Remittances and Aid Effectiveness in SSA}

It is possible that the low effectiveness of aid on savings is explained by the fact that when projects such as schools, roads, etc., are implemented using foreign aid, maintenance and sustainability of these infrastructure are provided by local governments. This can increase governments' consumption spending on staff, equipment, or maintenance costs and reduce the government available income for public saving and hence national saving.

However, a number of authors (Burnside and Dollar (2000), Easterly et al. (2003), Levine (2003), Clemens et al. (2004)) have raised other possible factors that explain the low effectiveness of aid in promoting development. Some of these factors are weak economic policies, lack of democracy and the presence of incentive problems. For these authors, it is possible that foreign aid is not appropriately used in a weak institutional and political environment. As these funds are primarily granted on the basis of poverty, receiving countries would be incited to implement bad development policies to benefit from foreign aid, or to qualify for some advantageous forms of international assistance. This phenomenon is known as the "Samaritan's dilemma" described by Buchanan (1975) where aid reduce the incentive and effort of the recipient.

On the other side, remittances, contrary to foreign aid, are directly received by poor households and people in needs and not by governments as intermediaries. One can suppose that this is the reason why remittances would be a more efficient way to allocate resources and serve households' interest than foreign aid. Even if the criticisms against foreign aid related to incentives problems are also raised in the literature 
analyzing the effectiveness of remittances, however, remittances are private funds whose use do not rely only on one user but two users, households and migrants themselves. Although the same factors (the incentive problems) raised in the literature to explain the low effectiveness of foreign aid can also make remittances ineffective, this can be mitigated by the existence of two potential holders of remittances and the willingness of migrants to use their funds in their countries for their own interests (investment for future return at the home country, retirement or individual project, etc.). The incentives problem related to remittances mentioned in the literature are therefore likely to affect households receiving money from their parents abroad but not migrants who have their own funds for their projects. Although migrants' families could be tempted to reduce their work effort and would not efficiently use the funds received, as they know they are insured by their relatives abroad, however, migrants have the objective to use some of their funds directly for productive projects.

As previously mentioned, much of the literature has emphasized that remittances are entirely used to meet households' consumption needs and therefore they can not be considered as a source of capital to finance development in migrants' home countries. Baldé (2009) finds that there is no direct influence of remittances on growth in SSA. However, the above results suggest that even if remittances do not have direct effects on growth, they can have indirect effects that go through certain channels of growth such as savings and investment. The use of these funds for savings or investment can be done either by households or through migrants themselves. Even if poor households prioritize basic consumption (food, clothing, ceremonies), migrants may use some funds towards productive activities. In a survey conducted by the "Comité Français pour la Solidarité Internationale (CFSI)" and published by the "Agence Française de Développement AFD” (2004), migrants from Mali, Senegal, Morocco, Comoros and Vietnam living in France classified their different motives to remit by importance and priority as follows: 1) Assist family; 2) Build houses; 3) Build community infrastructure (health services, schools ..); 4) Start a business; and 5) Open a saving account. This shows that even if the priority is to support family, savings and investment are part of the possible uses of migrants' remittances. According to the World Bank cited by Salomone (2006), there 
are at least four factors and conditions that may decide households and migrants in using remittances: 1) the degree of household dependency on remittances, the more they are dependent on these funds, the less they save and invest; 2) the nature of remittances' recipients, women are more concerned about smoothing their consumption; 3) the existence of a potential target destination for remittances (purchase of goods or education for example ); and 4) the level of households' recipients income and the existence of credit constraints. To this; we add the volume of remittances received. While a low amount received enable households to meet daily consumption needs, a relatively high amount allows for additional uses such as savings or investment.

It is therefore important to differentiate remittances that are sent for supporting family with priority to meet daily needs; in this case, migration is a family strategy that helps addressing households' poverty (Ndione and Lalou, 2005), to remittances sent by migrants for their personal interest. The use (productive or not) of remittances therefore depends on the motives that push migrants to send money, which can be either an altruistic motive or savings and investment motives. Some African and European banks have established agencies in countries with high immigration and emigration to capture migrants' savings and help them channel these savings towards productive projects in their home country. The "Compagnie de Banques Internationales de Paris CBIP", owned by CBAO, a Senegalese bank, was created for migrants' banking needs. As a result, thousands of migrants' bank accounts opened (Airault et al., 2008). The "Banque de l'Habitat du Sénégal BHS' has developed an international banking network to capture Senegalese migrants' savings with agencies created in some countries like the U.S. where three BHS agencies were established, two in New York and one in Atlanta (Ndione and Brokhuis, 2006).

The initial economic conditions and living standards influence and determine how remittances will be used along with the orientation towards productive or nonproductive activities. A relatively good initial economic situation allows for more opportunities to migrants and their families to use remittances for savings and investment. Moreover, it is this situation that allows resources mobilization to finance 
migration without contracting debt. This in turn allows households and migrants not to have future debt repayment, leaving more opportunities to save or invest future remittances. However, when migration is financed by debt, remittances will be used for several years to repay debt and meeting daily consumption needs. Thus, in the shortrun, financing migration by debt could motives for savings and investment.

For very poor migrants' families, priority is to raise their consumption level rather than saving or investing. We therefore believe that the levels of development and income in the migrants' home countries play a crucial role on remittances use as savings and investment. There must be a certain income and development threshold below which households and migrants do not have the capacity to save and invest remittances. This threshold could be composed of the basic consumption for household including food, clothing, etc. Thus, the macroeconomic conditions in countries and communities of origin could be crucial for a productive use of remittances, as these macro-economic conditions leading to migration may also limit opportunities for savings and investment of remittances.

Foreign aid, if efficiently used, can be an important complement to remittances as it may enable households to have this subsistence income and to be above the threshold income so they can use a larger share of remittances towards savings and investment. 


\section{Conclusion}

The objective of this paper is twofold: First, it investigates the macroeconomic impact of remittances and foreign aid on savings and investment in SSA; and second, it allows us to do a comparative analysis of the effectiveness of remittances and foreign aid in stimulating savings and investment in this region. Our results show that contrary to the pessimistic literature, remittances positively and significantly influence savings and investment in SSA. Therefore, remittances are not entirely spent on basic consumption needs; but are also either saved or invested. Interestingly, we find that although the volume of remittances are lower than foreign aid, the former influence more savings and investment in SSA. The impact of remittances is 6 to 7 times greater than that of foreign aid even though the amounts of aid to SSA represented more than 15 times the remittances for some years. Remittances help relax liquidity constraints and when invested, they can keep busy family members in countries where unemployment is high. However, when foreign aid is efficiently used, it can be an important complement to remittances by allowing vulnerable households to have income above the threshold subsistence level so they can use larger share of remittances for savings and investment purposes. Even if remittances do not have direct effect on growth, it can have indirect positive effect on growth through saving and investment.

This study therefore leaves us important questions. Is the positive impact of remittances (higher than the impact of aid) on key development variables in SSA a reason to stop foreign aid? Is it a sufficient reason to replace foreign aid which is a public capital flow that is increasingly criticized and unpopular in some developed countries by remittances that are private capital flows? For international institutions, remittances and foreign aid are important complements but not substitutes because remittances can not finance major public projects such as roads, railways, airports, contrary to development aid, at least when properly used. According to Grabel (2009), skeptics of foreign aid consider remittances as the new "private foreign aid" (Adelman (2003)) but remittances and other international private capital flows are not substitute 
neither for foreign aid nor for economic development strategies that mobilize and channel resources for development purpose. 


\section{APPENDICE}

Table 4 : Définition and source of variables

\begin{tabular}{|c|c|c|}
\hline Variables & Definition & Source \\
\hline GDPPC & $\begin{array}{l}\text { Real GDP per capita, } 2000 \\
\$ \text { constant }\end{array}$ & \multirow{9}{*}{$\begin{array}{l}\text { World } \\
\text { Development } \\
\text { Indicators } \\
\text { (2006), } \\
\text { World Bank }\end{array}$} \\
\hline REMIT & $\begin{array}{l}\text { Migrants’ Remittances, \% } \\
\text { GDP }\end{array}$ & \\
\hline AID & Foreign Aid, $\%$ GDP & \\
\hline INV & $\begin{array}{l}\text { Gross Fixed Capital } \\
\text { Formation ( } \% \text { of GDP) }\end{array}$ & \\
\hline GS & Gross savings, \% GDP & \\
\hline DEP INT & Deposit interest rate & \\
\hline LEND_INT & Lending interest rate & \\
\hline OPEN & $\begin{array}{l}\text { Openness as a ratio of } \\
\text { imports and exports on } \\
\text { GDP, } \%\end{array}$ & \\
\hline INFLAT & $\begin{array}{l}\text { Inflation rate mesured by } \\
\text { the change in Consumer } \\
\text { Price Index }\end{array}$ & \\
\hline
\end{tabular}

Table 5 : Descriptive Statistics for the "Savings Equation"

\begin{tabular}{|l|c|c|c|c|c|c|}
\hline & Mean & Median & Minimum & Maximum & Std.-dev. & Observations \\
\hline $\begin{array}{l}\text { Savings (\% } \\
\text { GDP) }\end{array}$ & 13.24 & 12.80 & -15.67 & 65.95 & 10.93 & 513 \\
\hline $\begin{array}{l}\text { GDP per capita } \\
\text { (\$ constant) }\end{array}$ & 832 & 328 & 75 & 7443 & 1232 & 513 \\
\hline $\begin{array}{l}\text { Remittances (\% } \\
\text { GDP) }\end{array}$ & $\mathbf{2 . 8 1}$ & 1.05 & 0 & 38.32 & 4.57 & 513 \\
\hline $\begin{array}{l}\text { Foreign Aid (\% } \\
\text { GDP) }\end{array}$ & $\mathbf{1 2 . 0 5}$ & 10.11 & -0.28 & 66.86 & 10.73 & 513 \\
\hline $\begin{array}{l}\text { Deposit interest } \\
\text { rate (nominal) }\end{array}$ & 9.16 & 7.5 & 2.43 & 39.33 & 6.61 & 513 \\
\hline Inflation & 10.55 & 6.81 & -13.06 & 122.87 & 15.13 & 513 \\
\hline
\end{tabular}


Table 6 : Descriptive Statistics for the "Investment Equation"

\begin{tabular}{|l|c|c|c|c|c|c|}
\hline & Mean & Median & Minimum & Maximum & Std. dev. & Observations \\
\hline $\begin{array}{l}\text { Investment (\% } \\
\text { GDP) }\end{array}$ & 20.18 & 18.75 & 5.49 & 51.81 & 7.33 & 411 \\
\hline $\begin{array}{l}\text { GDP per capita (\$ } \\
\text { constant) }\end{array}$ & 1023 & 423 & 75 & 7443 & 1337 & 411 \\
\hline $\begin{array}{l}\text { Remittances (\% } \\
\text { GDP) }\end{array}$ & $\mathbf{3 . 2 3}$ & 0.83 & 0.00 & 38.32 & 5.76 & 411 \\
\hline $\begin{array}{l}\text { Foreign Aid (\% } \\
\text { GDP) }\end{array}$ & $\mathbf{1 1 . 3 9}$ & 9.10 & -0.28 & 75.23 & 11.15 & 411 \\
\hline $\begin{array}{l}\text { Lending interest } \\
\text { rate (nominal) }\end{array}$ & 18.40 & 16.00 & 6.00 & 63.58 & 8.59 & 411 \\
\hline Openness & 77.14 & 61.28 & 6.32 & 195.56 & 41.00 & 411 \\
\hline Savings (\% GDP) & 14.76 & 13.76 & -13.29 & 65.95 & 11.36 & 411 \\
\hline
\end{tabular}




\section{REFERENCES}

Adams, R. H. Jr (1998), "Remittances, Investment, and Rural Asset Accumulation in Pakistan", Economic Development and Cultural Change, vol. 47, no1, pp155-73.

Adams, R. (2006), "Remittances, Poverty and Investment in Guatemala", in Ozden, C. and M. Schiff (eds), International Migration, Remittances and the Brain Drain, Chap. 2, Palgrave-Macmillan, pp53-80.

Adelman, C. (2003) 'The privatization of foreign aid: Reassessing national largess', in Foreign Affairs, vol.8, No.6, November-December, 9-14.

Airault et al. (2008), « Migrants : la fin de l'argent liquide », Jeune Afrique, Juin.

Azam, J-P. et Gubert, F. (2005), « Migrant Remittances and Economic Development in Africa : A review of evidence », Paper prepared for the AERC Plenary session, 29 May 2005, Nairobi.

BAD - Banque Africaine de Développement, (2009), Les transferts de fonds des migrants, un enjeu de développement : Les Comores, Mali, Maroc, Sénégal. Rapport, 84p., (http://www.afdb.org).

Baldé, Y. (2009), "Migrants' Remittances and Economic Growth in Sub-Saharan Africa", Laboratory of Economic Analysis and Prospective (LAPE), University of Limoges, France.

Burnside Craig \& David Dollar (2000), "Aid, Policies, and Growth". American Economic Review, vol. 90, No.4, pp847-68.

CFSI - Comité Français pour la Solidarité Internationale, 2004. Rapport Migration et phénomènes migratoires : Flux financiers, mobilisation de l'épargne et investissement local, Paris, AFD, 241 p.

Chami, R., Fullenkamp, C., \& Jahjah, S. (2003). Are Immigrant Remittance Flows a Source of Capital for Development? IMF Working Paper WP/03/189.

Clemens Michael, Radelet Steven, et Rikhil Bhavnani (2004), "Aid and Growth : The Current Debate and Some New Evidence", Center for Global Development.

Dollar David \& Easterly, William (1999), "The Search for the Key: Aid, Investment and Policies in Africa," Journal of African Economies, Oxford University Press, vol. 8, No.4, p546-77 
Easterly et al. (2003), "New Data, New Doubts: A comment on Burnside and Dollar's Aid, Policies, and Growth", American Economic Review. National Bureau of Economic Research working paper No. 9846, July.

Feldstein, M. and C. Horioka (1980), "Domestic Savings and International Capital Flows”, Economic Journal, vol. 90, p314-29.

Fischer, S. (1993), "The Role of Macroeconomic Factors in Growth", Journal of Monetary Economics, vol. 32, No.3, p485-512.

Fry, M. J. (1978), Money and capital or financial deepening in economic development? Journal of Money, Credit, and Banking; vol. 10, p464-75

Funkhouser, E. (1992), "Migration from Nicaragua: Some Recent Evidence," World Development, vol. 20, No.8, pp1209-18.

Grabel, I. (2009), "Remittances, Political Economy, and Economic Development"; International Institute of Social Studies, Erasmus University, Rotterdam.

Grabel, I. (2008), 'The political economy of remittances: What do we know? What do we need to know?' Political Economy Research Institute Working Paper No. 184 Univeresity of Massashusetts-Amherst.

Greene J. et D. Villanueva (1991), "Private Investment in Developing Countries", in IMF Staff Papers, No.38, p33-58. Washington, International Monetary Fund.

Gubert, F. (2000), "Migration, Remittances and Moral Hazard: evidence from the Kayes area (Western Mali)", Revised version of papers presented at the 8èmes journées du SESAME, Montpellier, 7-9 ${ }^{\text {th }}$ sept. 1998.

Gubert, F. (2002), "Do Migrants Insure Those Who Stay Behind: Evidence from the Kayes Area (Western Mali)", Oxford Development Studies, vol. 30, no3, pp267-287.

Gupta, K.L. and Islam, M.A. (1983), "Foreign Capital, Savings and Growth: An International Cross-Section Study", Dordrecht: Reidel Publishing Company.

Hansen, H. and Tarp, F. (2001), "Aide and Growth regressions", Journal of Development Economics, vol. 64, No 2; pp547-570.

Levine, R. (2003), “Do Aid Studies Govern Policies or Reflect Them”, The New York Times Company.

Levine, R. and D. Renelt (1992), "A Sensitivity Analysis of Cross-Country Growth Regressions", American Economic Review, vol. 82, No.4, p942-963. 
Lipton, M. (1980), "Migration from rural areas of poor countries: the impact on rural productivity and income distribution", World Development, vol. 8, p1-24.

López-Córdoba, E. (2004), "Globalization, Migration, and Development: The Role of Mexican Migrant Remittances”, Economia.

Massey, D. S, et al. (1987), "Return to Aztlán: The Social Process of International Migration from Western Mexico, Berkeley and Los Angeles: University of California Press.

Mesnard, A. (2004), "Temporary Migration and Self-Employment: Evidence from Tunisia", Brussels Economic Review, Special issue on skilled migration, vol. 47, no 1, pp119-138.

Mishra, P. (2005), "Macroeconomic Impact of Remittances in the Caribbean", Unpublished paper, International Monetary Fund, Washington, DC.

Mosley, P. (1987), Overseas Aid: Its Defence and Reform, Brighton: Wheatsheaf Books.

Hadjimichael, M. T., Ghura, D. Mühleisen, M., Nord, R. and Uçer, E. M. (1995), SubSaharan Africa: Growth, Savings, and Investment, 1986-93, Occasional Papers 118, Washington D.C.: International Monetary Fund.

Ndione B. et Broekhuis A. (2006), «Migration internationale et développement : Points de vue et Initiatives au Sénégal » Working papers Migration and Development series Report $n^{\circ}$ 8. Research group Migration and Development (Department of Human Geography), Radboud University, Nijmegen, The Netherlands. 30p.

Ndione B., Lalou R., (2005), «Tendances récentes des migrations internationales dans le Sénégal urbain : Existe-t-il une dynamique de quartier ? Les exemples de Dakar, Touba et Kaolack », Union Internationale pour l'Etude Scientifique de la Population XXVe Congrès International de la Population Tours, France, 18-23 juillet 2005.

OCDE (2005), Migration, transferts de fonds et développement, Objectif développement, Paris.

Ratha, D. (2003), "Workers Remittances: An Important and Stable Source of External Development Finance", Global Development Finance, Washington, World Bank, pp157-175.

Rempel, H. et Lobdell, R. (1978), "The role of Urban to Rural Remittances in rural development", Journal of Development Studies, vol 14, p324-341.

Roodman, D. (2005; 2009 update), “An Index of Donor Performance”, Working Paper 67, Center for Global Development. 
Salomone, S. (2006), "Remittances: Overview of the existing literature", Department of Economics, University of Rome "Tor Vergata".

Serven, L. et A. Solimano (1993). "Debt Crisis, Adjustment Policies, and Capital Formation in Developing Countries : Where Do We Stand ?", World Development, vol. 21, p.127-40.

Taylor, J. E. and al. (1996a), "International Migration and Community Development", Population Index, vol 62, no 3, pp397-418.

Wai, U. T. and C. Wong (1982). "Determinants of Private Investment in Developing Countries", Journal of Development Studies, vol. 19, p19-36.

Weisskopf, T., (1972), The Impact of Foreign Capital Inflows on Domestic Savings in Underdeveloped Countries, vol. 2; p25-38.

Woodruff, C. and Zenteno, R. (2001), "Remittances and Micro-Enterprises in Mexico", Mimeo, University of California at San Diego.

Woodruff, C. and R. Zenteno (2007): "Migration Networks and Microenterprises in Mexico", Journal of Development Economics, vol. 82, p509-528.

World Bank (2006), “Global Economic Prospects 2006 - Economic Implications of Remittances and Migration”, Washington DC.

World Bank, (2006), "World Development Indicators database and CD ROM", Washington, DC.

World Bank (2009); Remittances data 2009; World Bank staff estimates based on the International Monetary Fund's Balance of Payments Statistics Yearbook 2008, Washington DC.

World Development Report (2008), Agriculture for Development; The World Bank, Washington DC.

Yang, Dean (2004) "International Migration, Human Capital, and Entrepreneurship: Evidence from Philippine Migrants' Exchange Rate Shocks", Mimeo. Ford School of Public Policy, University of Michigan. 